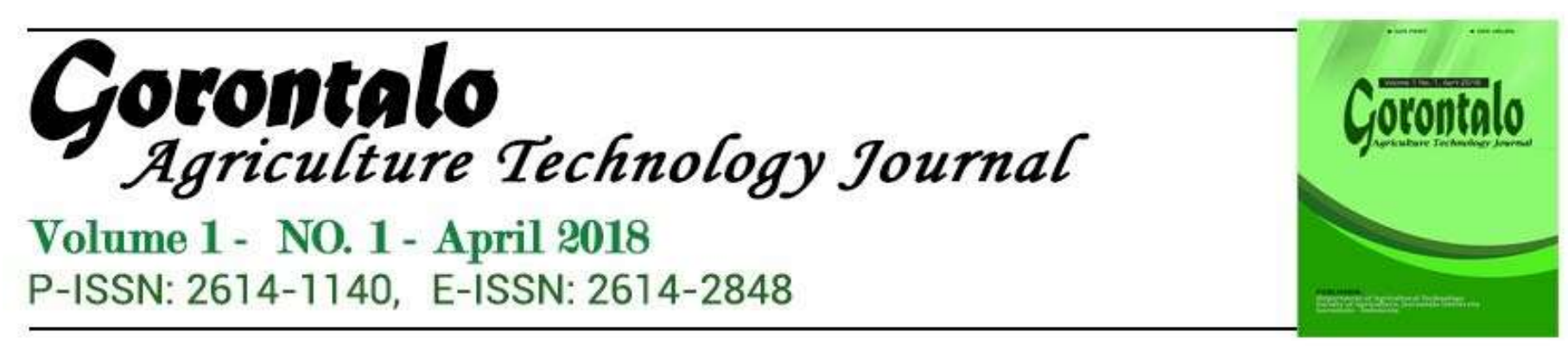

\title{
Pembuatan Bolu dengan Substitusi Tepung Pisang Goroho
}

\author{
Irwan Datunsolang1) \\ ${ }^{1}$ Teknologi Hasil Pertanian Fakultas Pertanian Universitas Gorontalo \\ email: irwan@gmail.com
}

\begin{abstract}
this research is to determine the manufacture of bolu substitution basic flour banana goroho. this study using the design of randomized complete (RAL) with three treatment three times replay, a1 formulated flour banana goroho $150 \mathrm{gr}$ and wheat flour 50gr, a2 formulated flour banana goroho 100gr and wheat flour 100gr, a3 formulated flour banana goroho50 grams and wheat flour 150gr. parameters analyzed is water content, ash content, level of carbohydrate and test organoleptic (color, taste, aroma and texture). the results showed that the treatment a2 with the formulation of flour banana goroho $100 \mathrm{gr}$ and wheat flour 100gr is the best treatment which can produce bolu preferred by panelists terms, taste, aroma and texture. scent that 4,00, sense that 4,23, and texture that 4,37. and have ash content meet the standards of quality National Indonesia and has a level of carbohydrate $18,37 \%$, water content $27,71 \%$ and ash content $1,30 \%$
\end{abstract}

Keywords : sponge, wheat flour, flour banana goroho

\section{PENDAhUluan}

Masyarakat Asia Tenggara telah lama memanfaatkan pisang. Di daerah itu, saat berkebudayaan pengumpul (food gathering), telah menggunakan tunas dan pelepah pisang sebagai bagian dari sayur. Bagian-bagian lain dari tanaman pisang pun telah dimanfaatkan (Satuhu dan Supriyadi, 1999). Pada saat ini hampir setiap orang gemar mengkonsumsi buah pisang (Sunarjono, 2002).

Pisang merupakan komoditas nasional yang dikembangkan dalam progam strategis kementerian pertanian yaitu pengembangan kawasan hortikultura. Produksi pisang di Provinsi Sulawesi Utara pada tahun 2016 adalah sebesar 233.124 ton, termasuk di dalamnya pisang lokal khas seperti pisang goroho. Namun informasi pemanfaatannya sebagai pisang olahan masih sangat terbatas.

Pisang layak digunakan sebagai bahan baku pembuatan tepung. Kandungan karbohidrat tepung pisang cukup tinggi, yaitu antara $70-80 \%$, 
sehingga dapat digunakan sebagai sumber kalori. Pada tahun 2017 konsumsi tepung terigu nasional mencapai 3,8 juta ton. Total kebutuhan tepung terigu sebesar itu setara dengan 4,5 juta hingga 5 juta ton biji gandum yang seluruhnya masih harus diimpor.

Dengan rata-rata rendemen tepung pisang lokal Sulawesi Utara sebanyak 30\% dan kadar karbohidrat sebesar 90\%, maka perlu dikaji teknologi pengolahan tepung pisang lokal sebagai substitusi tepung terigu menjadi produk seperti kue bolu yang diharapkan dapat meningkatkan nilai gizi sehingga dihasilkan kue bolu yang kaya protein dan serat.

Produk olahan pisang goroho dapat dihasilkan, baik sebagai bahan makanan, pakan ternak maupun bahan baku industri. Untuk lebih memanfaatkan pisang goroho dapat ditempuh dengan mengolahnya menjadi tepung dan bermanfaat sebagai bahan substitusi tepung terigu yang dapat diolah menjadi beberapa produk pangan. Tepung pisang goroho dibuat dengan langkah pembersihan dan pengupasan, pensawutan ataupun pengirisan, pengeringan, penepungan dan pengayakan hingga diperoleh produk dalam bentuk tepung halus. Tepung pisang goroho memiliki kandungan karbohidrat yang tinggi sehingga baik digunakan untuk menghasilkan aneka produk pangan yang mempunyai nilai gizi, seperti bolu.

Bolu merupakan produk olahan yang telah lama dikenal oleh masyarakat karena memiliki kandungan gizi yang cukup tinggi dan mudah dalam proses pengolahannya. Bahan baku pembuatan bolu adalah tepung terigu yang terbuat dari gandum, namun dapat disubtitusi dengan tepung pisang goroho. Bolu dengan bahan baku tepung pisang goroho membutuhkan protein dalam bentuk gluten yang dimiliki tepung terigu. Kemampuan gluten pada tepung terigu menghasilkan tekstur bolu menjadi empuk, meningkatkan cita rasa, sebagai sumber protein, dan sumber karbohidrat. Berdasarkan uraian tersebut, maka perlu dilakukan penelitian yang berjudul Studi Pembuatan Bolu Dengan Subtitusi Tepung Pisang Goroho.

\section{METODE PENELITIAN}

\subsection{Alat dan Bahan}

Alat yang digunakan pada penelitian ini adalah timbangan analitik, wadah, sendok, oven, mixer, loyang, pisau, spatula, labu ukur $100 \mathrm{ml}$, alat titrasi, tabung reaksi, pipet, kertas saring, cawan, oven desikator.

Bahan yang digunakan untuk penelitian ini adalah tepung terigu, TBM, tepung pisang goroho, telur, vanili, selai, margarine, gula halus.

\subsection{Metode Penelitian}

Penelitian ini menggunakan metode Rancangan Acak Lengkap (RAL) masing-masing perlakuan yang diulang sebanyak 3 kali. Adapun formulasi penggunaan tepung pisang goroho dan tepung terigu, yaitu :

A1 : Tepung pisang goroho $150 \mathrm{~g}$ dan tepung terigu $50 \mathrm{~g}$

A2 : Tepung pisang goroho $100 \mathrm{~g}$ dan tepung terigu $100 \mathrm{~g}$

A3 : Tepung pisang goroho $50 \mathrm{~g}$ dan tepung terigu $150 \mathrm{~g}$ 


\subsection{Prosedur Penelitian}

\section{Pembuatan Tepung Pisang Goroho}

a. Pisang goroho di awali dengan pengupasan pisang goroho.

b. Pisang di parut untuk mempercepat proses pengeringan.

c. Pisang dicuci untuk menghilangkan getah dan menghambat proses pencoklatan.

d. Setalah selesai dicuci pisang goroho di timbang.

e. Di rendam dengan menggunakan natrium metabisulfit selama 20 menit.

f. Pisang goroho di letakkan di atas wadah yang sudah di sediakan dan di keringkan dengan menggunakan oven dengan suhu $90^{\circ} \mathrm{C}$ selama 9 jam.

g. Dihaluskan dengan menggunakan ginder. Bubuk daging pisang goroho yang sudah dihaluskan kemudian di ayak dengan menggunakan ayakan 80 mesh.

\section{Pembuatan Bolu Pisang Goroho}

a. Masukan tepung pisang goroho dan tepung terigu sesuai perlakuan

b. Masukan gula halus $50 \mathrm{~g}, 5$ butir telur, TBM 1 sendok makan, vanili 2 bungkus, susu $100 \mathrm{ml}$ diaduk mengunakan mixer sampai mengembang.

c. Masukkan mentega cair ke dalam adonan aduk secara perlahan.

d. Masukan adonan pada loyang oven yang sudah di beralaskan aluminium foil yang dioles dengan mentega.

e. Masukkan dalam oven dan dipanggang hingga matang dan permukaan kulitnya berwarna kecoklatan.

f. Mengeluarkan dari Loyang dan didinginkan. Kemudian Diolesi dengan selai kemudian diiris lebar $4 \mathrm{~cm}$ dan panjang $6 \mathrm{~cm}$.

\subsection{Parameter Pengamatan}

\section{Kadar Air (Sudarmadji et al, 1984)}

Pengukuran kadar air sampel dilakukan dengan proses pengeringan. Prosedur kerja pengukuran kadar air sebagai berikut :

a. Cawan kosong dan tutupnya dikeringkan dalam oven selama 15 menit.

b. Ditimbang dengan cepat kurang lebih 2 g sampel yang sudah dihomogenkan dalam cawan.

c. Dimasukkan dalam cawan kemudian dimasukkan oven selama 3 jam.

d. Cawan didinginkan selama 15 menit. Setelah dingin bahan ditimbang kembali.

e. Bahan dikeringkan kembali ke dalam oven 30 menit sampai di peroleh berat yang tetap.

f. Bahan didinginkan kemudian ditimbang sampai diperoleh berat yang tetap.

g. Dihitung kadar air dengan rumus

\section{Kadar Abu (Sudarmadji et al, 1984)}

$$
\text { \%kadar air }=\frac{\text { berat awal }- \text { berat akhir }}{\text { berat akhir }} \times 100 \%
$$

a. Cawan pengabuan dibakar dalam tanur kemudian didinginkan 3-5 menit lalu ditimbang.

b. Ditimbang dengan cepat kurang lebih $2 \mathrm{~g}$ sampel yang sudah dihomogenkan dalam cawan. 
c. Dimasukkan dalam cawan petri pengabuan kemudian dimasukkan ke dalam tanur dan dibakar sampai didapat abu- abu atau sampai beratnya tetap.

d. Bahan didinginkan kemudian ditimbang.

e. Dihitung kadar abunya dengan rumus :

\section{Kadar Karbohidrat (Sudarmadji et al, 1984)}

$$
\% \text { kadar } a b u=\frac{\text { berat } \mathrm{abu}(\mathrm{g})}{\text { berat sampel }} \times 100 \%
$$

Kandungan karbohidrat dihitung secara by difference antara jumlah kandungan air,protein lemak dan abu dengan 100.

Rumus \% karbihidrat $(\mathrm{g} / 100 \mathrm{~g})=100-($ protein + lemak + abu + air $)$.

\section{Uji organoleptik (Rahayu, 2011)}

Uji organoleptik dilakukan untuk mengetahui tingkat kesukaan panelis terhadap produk. Pada pengujian ini ada 25 orang panelis yang memberikan penilaiannya berdasarkan tingkat kesukaannya terhadap produk meliputi warna, aroma, tekstur dan rasa. Pengujian yang dilakukan adalah menggunakan metode hedonik (uji kesukaan) dengan skala penilaian 1-5 yaitu (1) sangat tidak suka (2) tidak suka (3) agak suka (4) suka (5) sangat suka.

\section{HASIL DAN PEMBAHASAN}

\subsection{Kadar Air}

Air merupakan komponen penting dalam bahan makanan karena air dapat mempengaruhi penampakan, tekstur, serta cita rasa makanan. Kandungan air dalam bahan makanan menentukan acceptability, kesegaran, dan daya tahan bahan tersebut (Winarno, 2002). Oleh karena itu, dilakukan analisa kadar air dengan tujuan untuk mengetahui jumlah air yang terdapat pada produk bolu yang dihasilkan. Pengukurannya dilakukan dengan menggunakan cara basis kering. Jumlah kadar air dalam produk bolu akan berpengaruh terhadap tekstur maupun citarasanya.

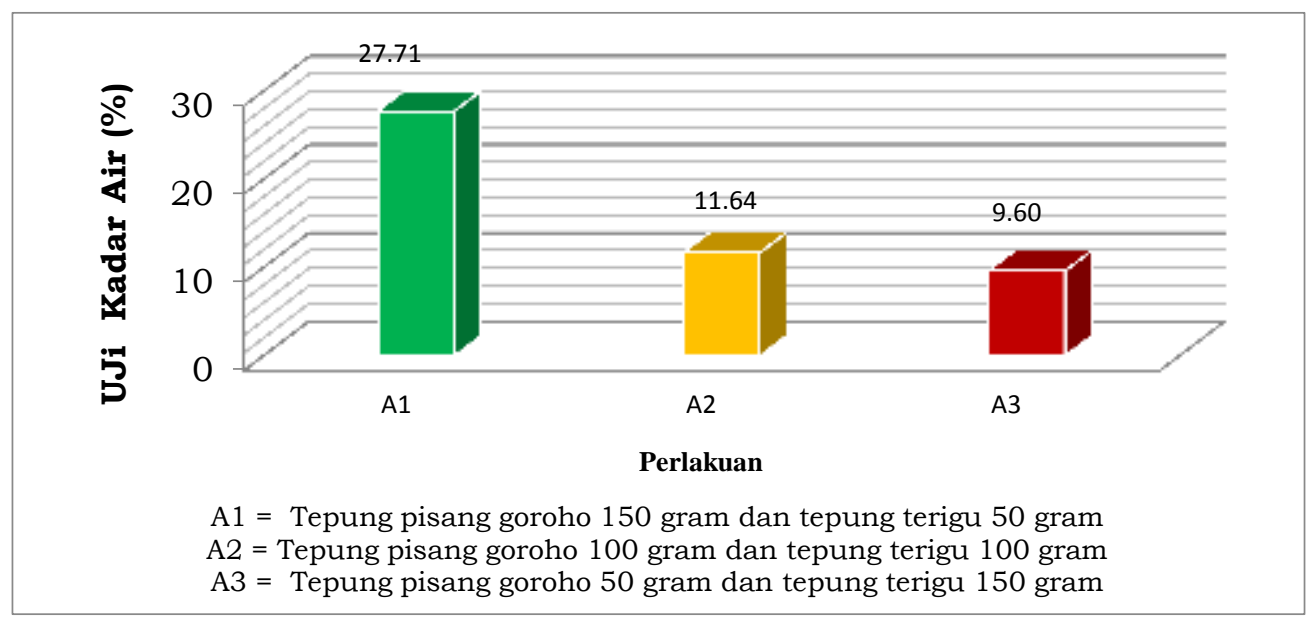

Gambar 1. Diagam Batang Kadar Air pada Bolu Tepung Pisang Goroho

Dari hasil analisis sidik ragam (lampiran 5a) menunjukkan bahwa perlakuan pada pembuatan kue bolu berpengaruh sangat nyata pada taraf $1 \%$. kadar air pada kue bolu yang terbaik adalah pada perlakuan A3 (tepung pisang goroho $50 \mathrm{~g}$ dan tepung terigu $150 \mathrm{~g}$ ) dengan kadar air 9,60. Semakin 
rendah penggunaan tepung pisang goroho semakin rendah pula kadar air. Dimana kadar air tepung pisang goroho 11,29 (Erny et al 2012 dalam Nawai 2015) dan kadar air tepung terigu 11,8 (daftar komposisi bahan makanan 2008 dalam Nawai 2015).

Kadar air yang tertinggi yaitu perlakuan A1 (tepung pisang goroho 150 dan tepung terigu 50 g) yaitu $27,71 \%$, sdangkan perlakuan A2 dengan formulasi tepung pisang goroho $100 \mathrm{~g}$ dan tepung terigu $100 \mathrm{~g}$ yaitu 11,64 , dan perlakuan A3 dengan formulasi tepung pisang goroho $50 \mathrm{~g}$ dan tepung terigu 150 g yaitu 9,60. Dari ketiga perlakuan memiliki kadar air yang tidak memenuhi standar nasional indonesia, sebab syarat mutu bolu adalah maksimal 5\%. (BPOM SNI 01-2973-1992).

\subsection{Kadar Abu}

Abu adalah zat anorganik dari hasil pembakaran suatu bahan organik. Kandungan komposisinya tergantung pada macam bahan dan cara penggabungannya. Kadar abu ada hubungannya dengan mineral suatu bahan, yaitu penggunaan tepung pisang goroho dan tepung terigu pada bolu yang memiliki kandungan mineral kalsium, fosfor, zat besi, kalium, magnesium, dan natrium. Kandungan kadar abu yang kecil pada produk bolu yang dihasilkan, disebabkan adanya proses pemanasan yang dilakukan dengan pengovenan, sehingga tidak menghasilkan zat anorganik (karbonat, khlorida, sulfat dan nitrat) yang merupakan sisa-sisa hasil pembakaran suatu bahan organik. Selain itu, kandungan kadar abu yang kecil dapat disebabkan dari margarine karena mengandung garam (Agus Krisno Budiyanto, 2002).

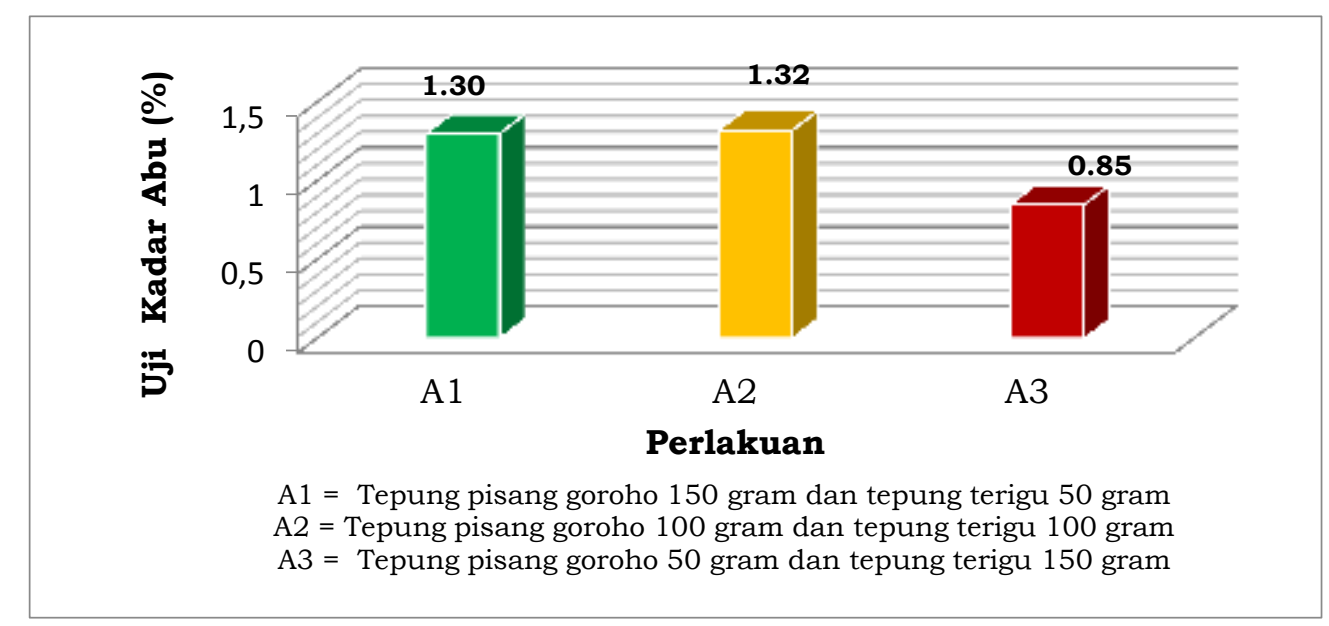

Gambar 2. Diagam Batang Kadar Abu pada Bolu Pisang Goroho

Kandungan kadar abu pada bolu yang dihasilkan dengan menggunakan formulasi tepung pisang goroho $100 \mathrm{~g}$ dan tepung terigu $100 \mathrm{~g}$ sebesar 1,32\%. Dari gambar 2 menunjukan persentase yang berbeda-beda dari setiap perlakuan. Dari semua perlakuan memenuhi standar mutu nasional indonesia, dimana syarat mutu kue bolu berdasarkan standar nasional indonesia adalah maksimal 1,5 \%. (BPOM SNI 01-2973-1992). 


\subsection{Kadar Karbohidrat}

Kandungan karbohidrat ini merupakan kandungan yang paling tinggi dari analisis proksimat lainnya. Karbohidrat merupakan sumber kalori utama dan beberapa golongan karbohidrat menghasilkan serat yang berguna bagi pencernaan, serta mempunyai peranan penting dalam menentukan karakteristik bahan makanan misalnya rasa, warna, tekstur dan lain-lain. Karbohidrat selain berperan sebagai sumber energi utama juga berperan mencegah pemecahan protein tubuh secara berlebihan, kehilangan mineral dan membantu dalam metabolisme lemak dan mineral (Winarno, 2004).

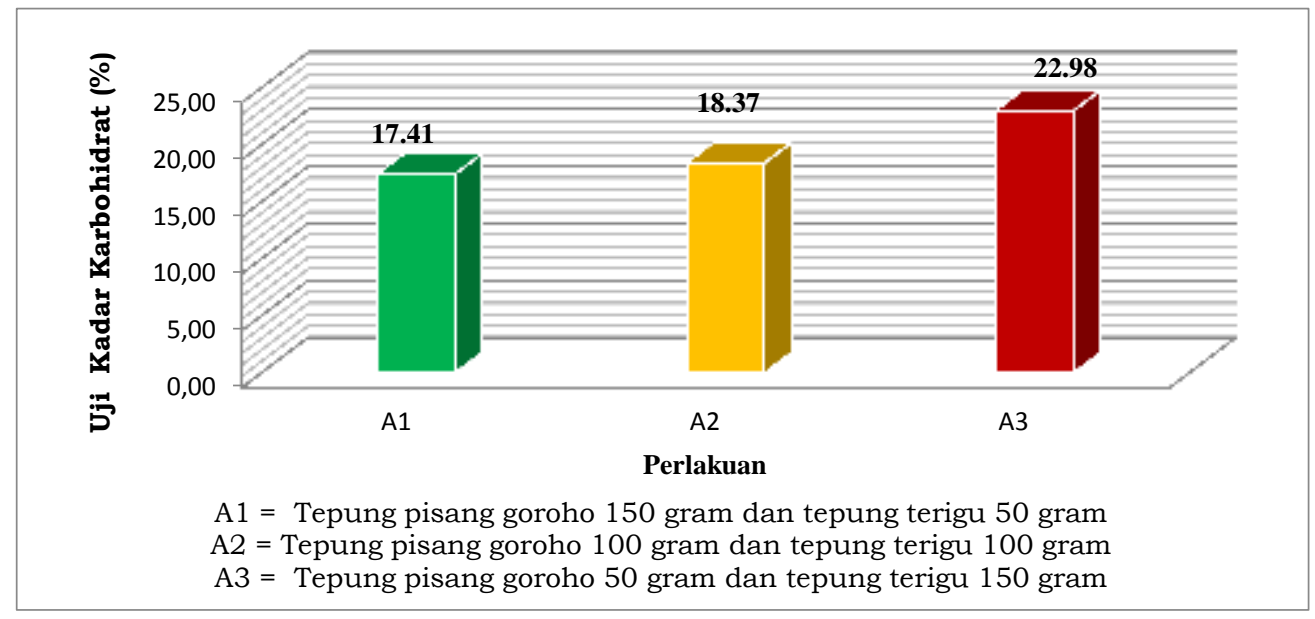

Gambar 3. Diagam Batang Kadar Karbohidrat pada Bolu Pisang Goroho

Perlakuan A1 dengan formulasi tepung pisang goroho $150 \mathrm{~g}$ dan tepung terigu $50 \mathrm{~g}$ yaitu $17,41 \%$. Perlakuan A2 dengan formulasi tepung pisang goroho $100 \mathrm{~g}$ dan tepung terigu $100 \mathrm{~g}$ yaitu $18,37 \%$. Perlakuan A3 dengan formulasi tepung pisang goroho $50 \mathrm{~g}$ dan tepung terigu $150 \mathrm{~g}$ yaitu 22,98\%. Hal ini disebabkan dari hasil analisis sidik ragam menunjukkan bahwa perlakuan pada pembuatan kue bolu berpengaruh nyata pada taraf $1 \%$. Hal ini disebabkan penggunaan tepung pisang goroho dan tepung terigu yang berbeda-beda pada setiap perlakuan.

\subsection{Organoleptik Rasa}

Rasa adalah faktor berikutnya yang dinilai panelis setelah tekstur, warna dan aroma. Rasa timbul akibat adanya rangsangan kimiawi yang dapat diterima oleh indera pencicip atau lidah. Rasa adalah faktor yang mempengaruhi penerimaan produk pangan. Tingkat rasa produk bolu yang dihasilkan dipengaruhi oleh penggunaan tepung pisang goroho dan bahan tambahan (Winarno,2004).

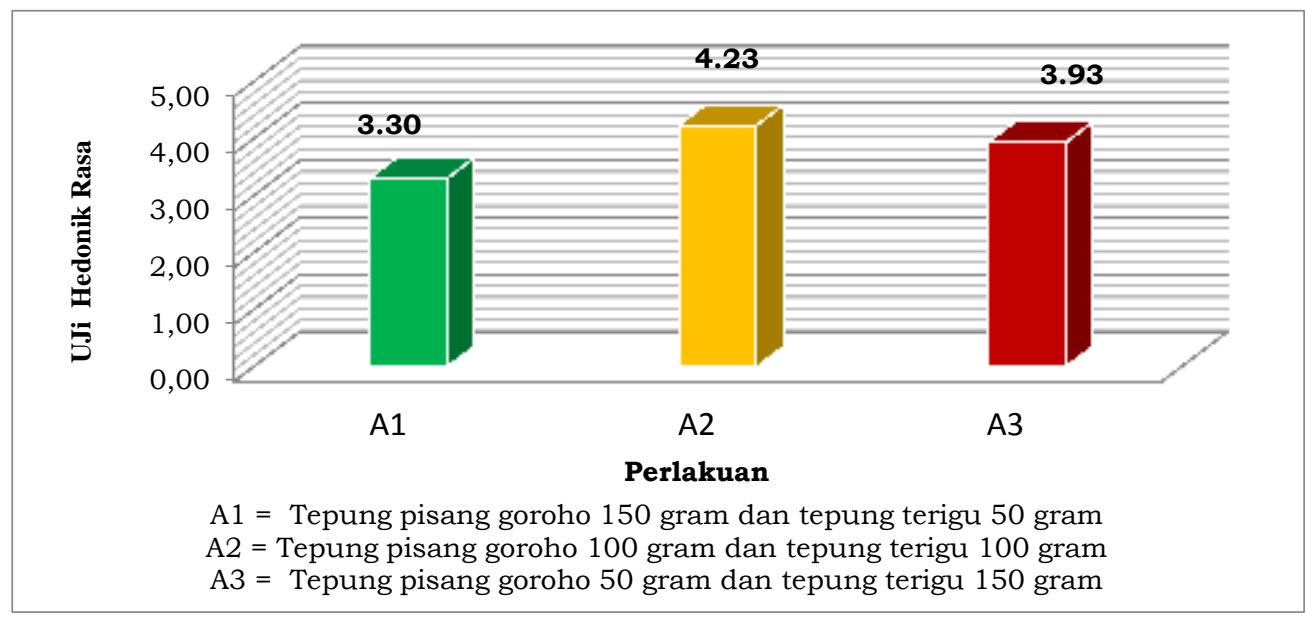


Hasil uji organoleptik terhadap rasa bertujuan untuk mengetahui tingkat respon dari panelis mengenai kesukaannya terhadap bolu yang dihasilkan pada masing-masing perlakuan. Hasil penilaian panelis pada gambar 6 menunjukkan bahwa bolu yang diperoleh dari 3 perlakuan memberikan rasa agak suka sampai suka. Hasil nilai rata-rata penilaian dari panelis dengan menggunakan metode hedonik melalui pengujian organoleptik, panelis memberikan nilai skor terhadap rasa bolu yaitu 3,3-4,15 (agak sukasuka). Hasil uji organoleptik terhadap rasa bolu yang dihasilkan menunjukkan bahwa rasa produk bolu yang paling disukai oleh panelis yaitu pada perlakuan A2 (tepung pisang goroho $100 \mathrm{~g}$ dan tepung terigu 100g) dengan skor 4,23. Pada perlakuan A1 (tepung pisang goroho $150 \mathrm{~g}$ dan tepung terigu $50 \mathrm{~g}$ ) memiliki skor 3.30 agak disukai oleh panelis dan perlakuan A3 (tepung pisang goroho $50 \mathrm{~g}$ dan tepung terigu $100 \mathrm{~g}$ ) memiliki 3,93 agak disukai oleh panelis. Adanya respon dari panelis yang relatif berbeda diduga ada hubungan dengan tekstur produk bolu yang dihasilkan.

\subsection{Organoleptik Tektur}

Tekstur memiliki pengaruh penting terhadap produk bolu misalnya dari tingkat kelembutan, keempukan, dan kekerasan, dan sebagainya. Teksturpada bolu dipengaruhi oleh bahan-bahan yang dicampurkan menjadi adonan.

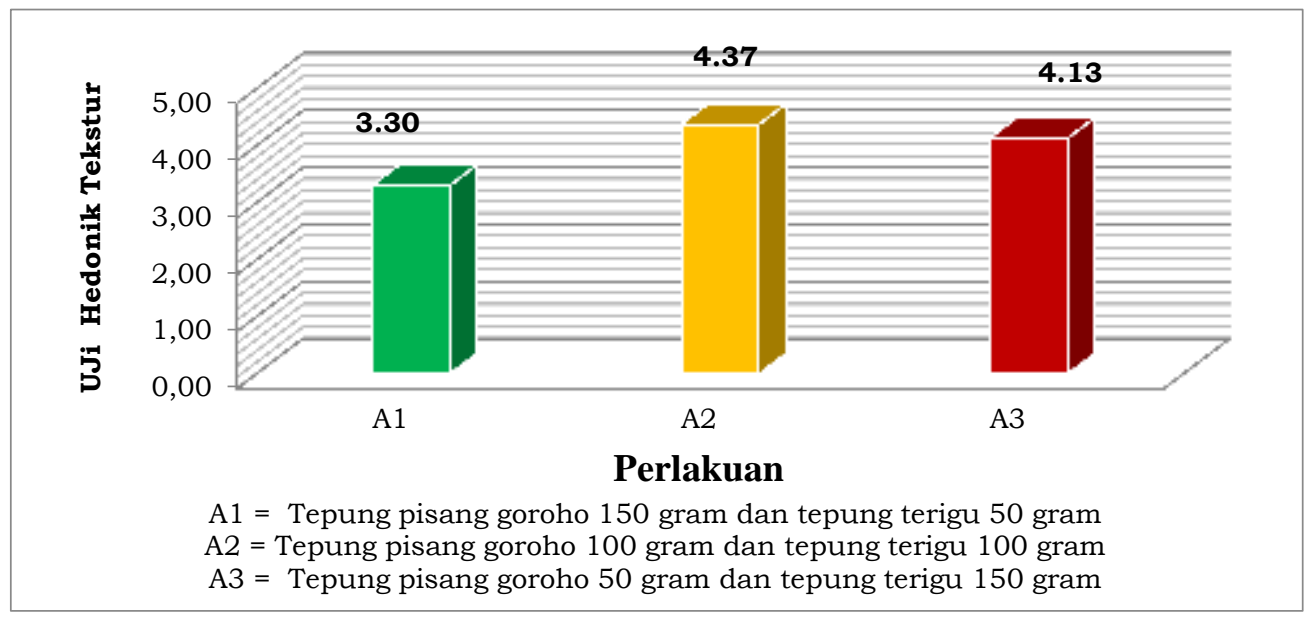

Gambar 5. Diagam Batang Uji Hedonik Tekstur pada Bolu Pisang Goroho

Hasil penilaian panelis pada gambar 5 menunjukkan bahwa bolu yang diperoleh dari 3 perlakuan memberikan tekstur agak suka sampai suka. Hasil nilai rata-rata penilaian dari 10 panelis dengan menggunakan metode hedonik melalui pengujian organoleptik, panelis memberikan nilai skor terhadap tekstur bolu yaitu 3,30-4,37 (agak suka- suka). Hasil uji organoleptik terhadap tekstur menunjukkan tekstur yang paling disukai oleh panelis adalah bolu pada perlakuan A2 (tepung pisang goroho $100 \mathrm{~g}$ dan tepung terigu 100g) dengan skor 4,37, dan yang agak disukai oleh panelis adalah tekstur bolu pada perlakuan A1 (tepung pisang goroho $150 \mathrm{~g}$ dan tepung terigu $50 \mathrm{~g}$ ) dengan skor 3,30,sedangkan tekstur bolu pada perlakuan A3 (tepung pisang goroho $50 \mathrm{~g}$ dan tepung terigu $150 \mathrm{~g}$ ) memiliki skor 4,13oleh panelis perlakuan ini dalam skala suka. Panelis memberikan skor yang berbeda-beda terhadap 
tekstur bolu yang dihasilkan disebabkan oleh penggunaan tepung pisang goroho dan tepung terigu yang berbeda-beda pada setiap perlakuan.

Penggunaan bahan baku tepung pisang goroho dan tepung terigu mempengaruhi tekstur bolu yang dihasilkan. Tekstur bolu berkaitan erat dengan komposisi bolu tesebut, komposisi tersebut adalah tepung terigu. Menurut Desrosier (2008), tepung terigu merupakan struktur pokok atau bahan pengikat di dalam semua formula cake (bolu). Bahan yang digunakan untuk memproduksi cake (bolu) memiliki pengaruh pengikat dan pengeras yang berbeda-beda terhadap adonan cake (bolu). Penggunaan tepung terigu yang berlebih menghasilkan tekstur bolu yang lebih lunak dan lebih beremah, sedangkan penggunaan tepung pisang goroho yang berlebih menghasilkan tekstur bolu yang lebih keras dan tidak mengembang. Menurut Winarno dan Pudjaatmaka (1989), tepung pisang goroho tidak memiliki protein gliadin dan glutenin yang dapat membentuk gluten, sedangkan tepung terigu mengandung protein dalam bentuk gluten. Gluten inilah yang menyebabkan produk bolu lebih mengembang.

\subsection{Organoleptik Warna}

Warna merupakan komponen yang sangat penting untuk menentukan kualitas atau derajat penerimaan suatu bahan pangan. Suatu bahan pangan meskipun dinilai enak dan teksturnya sangat baik, tetapi memiliki warna yang kurang sedap dipandang atau memberi kesan telah menyimpang dari warna yang seharusnya, maka seharusnya tidak akan dikonsumsi. Penentuan mutu suatu bahan pangan pada umumnya tergantung pada warna, karena warna tampil terlebih dahulu (Winarno, 2004).

Warna produk pangan adalah salah satu sifat organoleptik yang terdapat pada produk pangan. Faktor-faktor yang mempengaruhi warna dari produk bolu adalah penggunaan gula, telur dan tepung pisang goroho. Warna dapat memberikan penilaian yang berbeda terhadap pemakaian tepung pisang goroho yang baik. Bolu yang dihasilkan pada penelitian ini menggunakan tepung pisang goroho yang telah jadi.

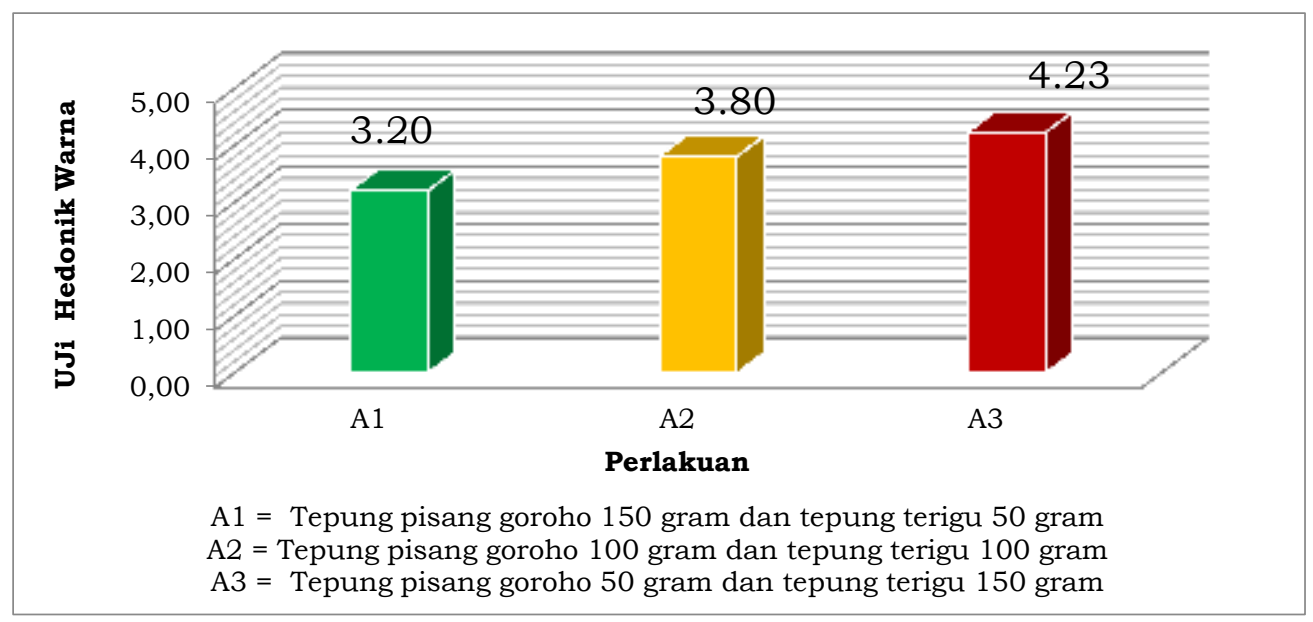

Gambar 6. Diagam Batang Uji Hedonik Warna

Hasil penilaian panelis pada gambar 3 menunjukkan bahwa bolu yang diperoleh dari 3 perlakuan memberikan warna tidak suka sampai suka. Hasil nilai rata-rata penilaian dari 10 panelis dengan menggunakan metode hedonik 
melalui pengujian organoleptik, panelis memberikan nilai skor terhadap warna bolu yaitu 3,20-4,23 (agak suka-suka). Hasil uji organoleptik terhadap warna menunjukkan warna yang paling tertinggi penilaian oleh panelis adalah bolu pada perlakuan A3 (tepung pisang goroho $50 \mathrm{~g}$ dan tepung terigu $150 \mathrm{~g}$ ) dengan skor 4,23 (suka), dan oleh panelis agak suka adalah warna bolu gulung pada perlakuan A1 (tepung pisang goroho $150 \mathrm{~g}$ dan tepung terigu $50 \mathrm{~g}$ ) dengan skor 3.20 , dan A2 (tepung pisang goroho $100 \mathrm{~g}$ dan tepung terigu $100 \mathrm{~g}$ ) memiliki skor 3.80 (suka). Skor yang berbeda tersebut disebabkan oleh penggunaan tepung pisang goroho dan tepung terigu. Tepung pisang goroho dan tepung terigu memberikan kontribusi warna terhadap produk bolu yang dihasilkan. Jumlah tepung pisang goroho dan tepung terigu yang digunakan memberikan pengaruh terhadap warna yang dihasilkan pada produk tersebut.

Warna keseluruhan bolu yang hampir tidak berbeda satu sama lainnya mengakibatkan panelis tidak mampu membedakan warna bolu dari setiap perlakuan. Inilah yang menyebabkan ketidak teraturan nilai skor warna bolu yang diperoleh. Warna bolu yang dihasilkan pada perlakuan A3 (tepung pisang goroho $50 \mathrm{~g}$ dan tepung terigu $150 \mathrm{~g}$ ) lebih disukai, sedangkan warna yang dihasilkan pada perlakuan A1 (tepung pisang goroho $150 \mathrm{~g}$ dan tepung terigu 50g) agak suka karena memiliki warna coklat kegelapan dan terlihat kurang menarik dari perlakuan lainnya. Penambahan tepung pisang goroho yang lebih banyak dari tepung terigu menimbulkan warna yang tidak disukai panelis, karena tepung pisang goroho yang digunakan memiliki warna gelap dibandingkan tepung terigu. Menurut Suismono (2001) tepung pisang goroho yang dihasilkan berwarna gelap disebabkan oleh adanya reaksi maillard (reaksi nonenzimatis) pada pisang goroho saat diolah menjadi tepung. Reaksi maillard adalah reaksi antara karbohidrat dan asam amino yang menyebabkan terjadinya pencoklatan. Untuk menghindari terbentuknya warna coklat pada pisang goroho, harus diusahakan semaksimal mungkin tidak kontak udara dengan cara merendam pisang goroho yang telah dikupas dalam air bersih atau dengan cara dikukus.

\section{KESIMPULAN DAN SARAN}

\subsection{Kesimpulan}

1. Dari hasil penelitian dapat di ambil kesimpulan bahwa karateristik bolu dengan subtitusi tepung pisang goroho memberikan pengaruh terhadap parameter yang diamati.

2. Sesuai dengan tingkat kesukaan panelis baik Rasa, aroma dan tekstur bolu dari tepung pisang goroho dengan formulasi tepung pisang goroho100 $\mathrm{g}$ dan tepung terigu $100 \mathrm{~g}$ diterima dan di sukai panelis serta mengandung karbohidrat $18,37 \%$.

\subsection{Saran}

Untuk penelitian selanjutnya adalah sebaiknya dilakukan penelitian pendugaan umur simpan produk bolu yang menggunakan tepung pisang goroho. 
5. REFERENSI

Desrosier, 2008. Teknologi Pengawetan Pangan. Penerjemah M.Muljohardjo. UIPress, Jakarta.

Pratomo, Aris. 2013. Studi Eksperimen Pembuatan Kue Bolu Kering Subtitusi Tepung Pisang Ambon. Teknologi Jasa Dan Produksi, Fakultas Teknik, Universitas Negeri Semarang.

Siregar, H. Julianti Ria. 2011.Pengaruh Perbandingan Tepung Terigu Dengan Tepung Talas dan Konsentrasi Karboksimetil Selulosa (CMC) Terhadap Mutu Roti Tawar. Universitas Sumatera Utara. http:/ 123456789/22564/4/Chapter\%20II.pdf.

Muchtadi, D. 2001. Sayuran sebagai sumber serat pangan untuk mencegahtimbulnya penyakit degeneratif.Jurnal Teknologi dan Industri Pangan. 12:61-71.

Suismono, 2001.Teknologi pembuatan tepung dan pati ubi-ubian untukmenunjang ketahanan pangan. Di dalam: Majalah Pangan Vol. X No. 37:37-49. Puslitbang Bulog, Jakarta.

Subarna.1996. Formulasi Produk-produk Serealia dan Umbi-umbian UntukProduk Ekstrusi, Bakery, dan Penggorengan.Makalah.Pelatihan Produk-produk Olahan, Ekstrusi, Bakery, dan Frying, Jakarta. 